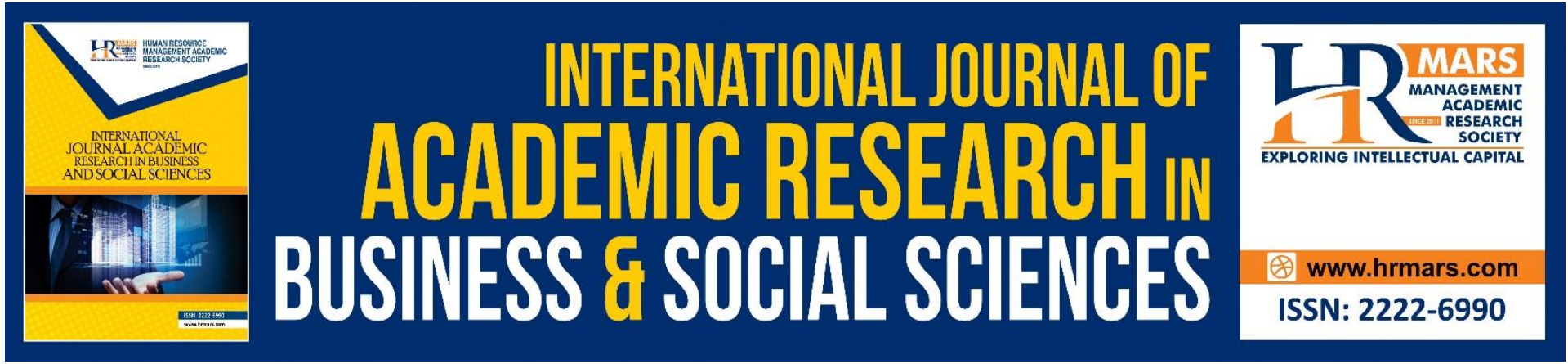

\title{
Ramen Among Millennials: Display of Mediational Process in Social Learning
}

Nur Anisah Tan, Mohd Hassan Awang Boon, Ulaya Ahdiani, Rosi Rosiah, Nadiah Zubbir, Noor Hanim Rahmat

To Link this Article: http://dx.doi.org/10.6007/IJARBSS/v11-i8/10750

DOI:10.6007/IJARBSS/v11-i8/10750

Received: 24 June 2021, Revised: 27 June 2021, Accepted: 10 August 2021

Published Online: 28 August 2021

In-Text Citation: (Tan et al., 2021)

To Cite this Article: Tan, N. A., Boon, M. H. A., Ahdiani, U., Rosiah, R., Zubbir, N., \& Rahmat, N. H. (2021). Ramen Among Millennials: Display of Mediational Process in Social Learning. International Journal of Academic Research in Business and Social Sciences, 11(8), 1803-1818.

Copyright: (c) 2021 The Author(s)

Published by Human Resource Management Academic Research Society (www.hrmars.com)

This article is published under the Creative Commons Attribution (CC BY 4.0) license. Anyone may reproduce, distribute, translate and create derivative works of this article (for both commercial and non-commercial purposes), subject to full attribution to the original publication and authors. The full terms of this license may be seen

at: http://creativecommons.org/licences/by/4.0/legalcode

Vol. 11, No. 8, 2021, Pg. 1803 - 1818

http://hrmars.com/index.php/pages/detail/IJARBSS

JOURNAL HOMEPAGE

Full Terms \& Conditions of access and use can be found at http://hrmars.com/index.php/pages/detail/publication-ethics 


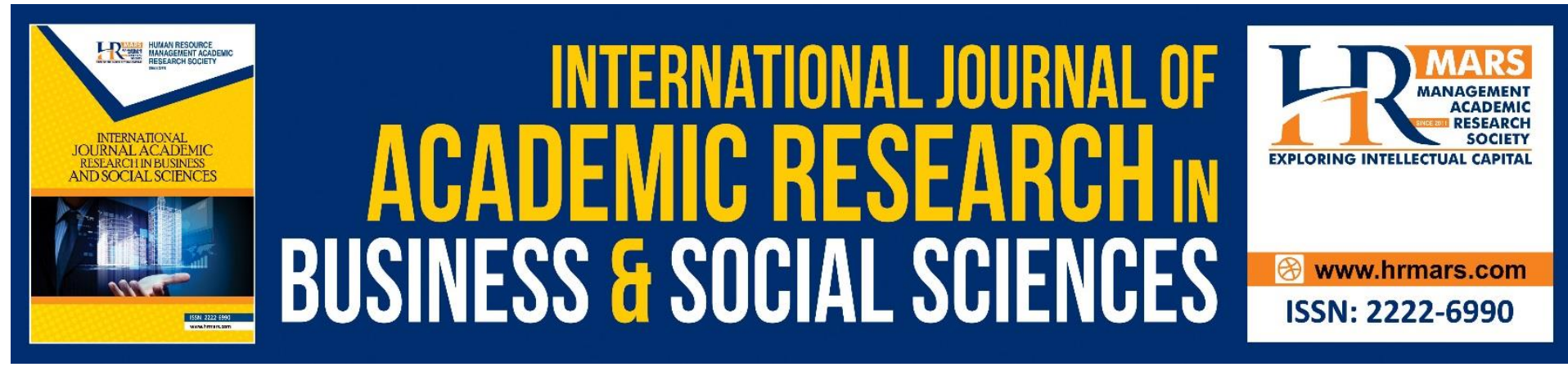

\title{
Ramen Among Millennials: Display of Mediational Process in Social Learning
}

\author{
Nur Anisah Tan ${ }^{1}$, Mohd Hassan Awang Boon², Ulaya Ahdiani ${ }^{3}$, \\ Rosi Rosiah ${ }^{4}$, Nadiah Zubbir ${ }^{5}$, Noor Hanim Rahmat ${ }^{6}$ \\ 1,2,5Akademi Pengajian Bahasa, Universiti Teknologi MARA, Shah Alam, Malaysia \\ ${ }^{3}$ Faculty of Literature, Culture and Communication, Universitas Ahmad Dahlan, Indonesia \\ ${ }^{4}$ Faculty of Language Education, Universitas Muhammadiyah, Yogyakarta, Indonesia \\ ${ }^{6}$ Akademi Pengajian Bahasa, Universiti Teknologi MARA, Pasir Gudang, Malaysia \\ Email:anistan@uitm.edu.my, mohdh218@uitm.edu.my, ulaya.ahdiani@enlitera.uad.ac.id, \\ rosi.rosiah@umy.ac.id,nadiahzubbir@uitm.edu.my,noorh763@uitm.edu.my
}

\section{Abstract}

Globalization has enabled people to live in a borderless world. People interact openly and conveniently with people from across the globe. As such, they are often being introduced to new ways of doing things. Language is no longer a barrier as many are learning foreign languages for their own reasons. One way people immerse themselves in another culture is by mirroring the other culture-their food. This study investigates the emergence of fast food called Ramen that has changed the way people around the world look at their fast food consumption. 530 participants from several countries responded to a survey asking their perception of the consumption of Ramen. Findings in this study have shown that young adults turn to Ramen for its convenience and its availability. The next findings also showed that respondents felt they were immersing themselves in the culture that they liked. Finally, findings also showed that many have turned to consumption as a way of their life. Findings in this study can pave more future studies on the relationship of language, culture, and food.

Keywords: Ramen, Culture, Way Of Life, Language, Immerse

\section{Introduction}

Background of Study

The millennial generation is also known as Generation $Y$. The youths of Generation $Y$ are known as such because of their nature to question the actions of parents or any authoritarian body that orders and controls them (Sheahan, 2011; Rabbani, 2015). In addition, Taylor et al (2010) stated that generation $Y$ dominates digital technology and social media as users compared to other generations. The users from Generation $Y$ are known to be able to multi-task with various gadgets in diverse situations.

Millennial Y lives in the world of digital gadgets. According to Rabbani (2015), they are obsessed with the popular culture of digital media that dominates their thoughts, attitudes, and actions. Japanese comics such as manga are popular among the youth of Generation $Y$ and later, followed by Japanese animation called anime. Hidayat \& Hidayat (2020) found that 
Generations $Y$ and $Z$ in Indonesia are influenced by acculturation in intercultural communication such as language, fashion, cuisine, and Japanese values from the manga and anime. Basaran \& Sünnetçioğlu (2021) found that anime contributes hugely to the cultural reflection of Japanese cuisine. While food-themed anime allows viewers to try Japanese food, it also encourages them to buy Japanese culinary products and to cook them at home. Consequently, anime causes almost half of the participants to be curious about Japanese cuisine and influences them to experience it.

In this light, instant noodles, which are part of Japanese food, are eaten by millions of consumers around the world, regardless of lifestyle, status, or age. Errington et al (2013) has conducted research on noodles and they discovered that the noodles were delicious, easy, and inexpensive. These elements make instant noodles one of the most highly demanded foods produced in the food industry. Similarly, Choong et al (2012) investigated the choice and frequency of high sodium food intake commonly consumed by 300 university students in Malaysia and uncovered that one of the popular foods is instant soup noodles.

\section{Statement of Problem}

Studying the culture of the target foreign language plays an important role in foreign language learning. According to Mazari \& Derraz (2015), one of the three important components in learning a foreign language is it offers learners the ability to understand the relationship between language and other cultural aspects of the native speakers. Culture Immersion-activity integrates learners into an unfamiliar community, encourages learners to interact with local people, and helps learners to seek ways to understand others who live in related communities by being there and engaging in daily life activities.

The present society is experiencing a change in lifestyle at the beginning of the $21^{\text {st }}$ century where one tends to have multiple tasks to do daily. As such, Sheahan (2008) said that Generation $Y$ grew up in a time-compressed society. Most tasks are expected to be done instantly and on-demand which induce Generation $Y$ to consume fast food including instant noodles (Errington et al., 2013; Choong et al., 2012).

The changes in the lifestyle of the millennials also influence their choices of food, place, and reasons they dine in. Seo et al (2011) mentioned that current youngsters do not take fast food as their main meals but more due to social interaction with friends, meetings, or celebrations.

Consumers usually purchase food and other products that they are familiar with. However, there are differences in intention to purchase Japanese food products between groups who know the Japanese language and those who do not Aznur et al (2015). Not being able to read and understand the information written on a product makes consumers less interested in buying them. Therefore, language proficiency is important when making decisions to purchase products if the description is written in a foreign language.

Generation $Y$ prefers fast food due to changes in lifestyle, cultural influences, development of knowledge and others. Looking at the trend and pattern of fast food in the Malaysian market, Habib et al (2011) reported that consumers spend more on fried chicken and instant noodles the least.

As a result, eating habits issues are becoming more common among recent university students. For instance, Dzulkafli et al (2020) discovered that university female students' favourite food, as well as food that they frequently consumed late at night, were instant noodles. Similarly, one of the favourite instant noodles in Malaysia is ramen which is eaten 
late at night. Late-night eating habits should be given attention as unhealthy food choices will lead to unhealthy weight gain.

Hence, this study was conducted to explore cultural immersion through ramen. Specifically, it was conducted by relating mediational processes to the issues of ramen.

1.3 Objective and Research Questions

1.3.1 How is observation done through ramen? (perception)

1.3.2 How is a reproduction of habits done through ramen? (Social interaction)

1.3.3 How is motivation enhanced through ramen? (Study patterns)

\section{Literature Review}

Social Learning Theory

Learners, when learning, process information based on the relationship between their behaviour and the consequences (Bandura, 1977). Edinyang (2016) relates Bandura's theory by saying the ability of learners to imbibe and display the behaviours exhibited with their environment. In the environment of learners' foreign language, they are always exposed not only to the language but also the culture. Learners will observe the cultural aspect through lectures, movies, amines, and others. They will then choose one or two of the elements that are interesting to them, imitate and adopt them. Culture immersion in fashions, cuisine, and style of communication are some of the examples.

Lusiana et al (2020) investigated the influence of Japanese culture in Purwokerto City, Central Java, Indonesia and showed how globalization generates positive thoughts, ideas, and responses related to local products, and influences local values and culture. One of them is Japanese food. The positive observation through the media, not only the influence of Japanese food consumption but also founded eleven (11) Japanese culture lover communities, the establishment of Japanese Literature Study Program in Jenderal Soedirman University and annual celebrations of Japanese events. At the end of the article, the researchers wrote:

'The presence of Japanese food is one factor of the emergence of a new lifestyle, namely the Japanese lifestyle'.

Therefore, individuals do not automatically observe the behaviour of a model and imitate it. There is some thought prior to imitation, and this consideration is called mediational processes. This occurs between observing the behaviour (stimulus) and imitating it or not (response)

\section{The Influence of Culture Immersion on Foreign Language Learning}

It is important to know the culture of the country when learning the language. According to Kramsch (2013), in foreign language education, the teaching of culture remains a debatable issue. There are many to define, i.e., about culture, about the relation of culture and language, about what culture should be taught, about the role of the learner's culture in receiving the knowledge of the target culture, and about how to develop intercultural competence. However, in language learning, culture plays a critical role because the language makes communication happen, allowing members of a society to be involved in social and interactive activities that can support them to actively join the academic society (Pourkalhor \& Esfandiari, 2017). Therefore, gaining knowledge about the language and being aware of beliefs and values that frame the language to be in line with the culture is important in 
learning a language (Pourkalhor \& Esfandiari, 2017). This means that it will be much more beneficial when a person learns a foreign language through the native speakers' culture.

Hence inserting the knowledge of the culture during the teaching and learning of a foreign language is important. Kostikova et al (2018) found that teaching cultural aspects of the target language makes the language learners more capable and socially skilled in the diverse world. Hence these findings should be put into attention. Language is the carrier and reflection of culture. Without language, culture would not exist. The basic goal of learning a foreign language is to achieve communicative capability (Sun, 2013). Thus, this shows that language and culture are two intermingling elements that are equally important to be learnt.

Sun's idea is in accordance with Li's, who states that language is the carrier as well as influencing culture. Culture is any product shared by all societies and any form of one nation's activities. Language is part of the culture and has an important role in cultural development. It is the basis of culture, that without language, culture will not exist, and vice versa (Li, 2014). In the meantime, foreign language educators must understand that they must teach foreign cultures to develop the learner's intercultural communication competence. But many language teacher's world universities and colleges face problems when they are required to teach culture in foreign language education (Sun, 2013). According to Li (2014), in foreign language teaching, teachers must introduce the cultural background and the content of its language, integrating language learning into the social culture and achieving the best target. From these elements, as hard as it gets, it is an important thing to have cultural immersion in foreign language learning to make language learning successful.

\section{Assimilation of Culture through Food and Social Gatherings}

In a multiracial country like Malaysia, assimilation of culture always happens through food and gatherings. Kramsch (1993) defines culture as "participation in a discourse society that shares a shared system of criteria for perceiving, believing, judging, and acting" (p. 127). This is because one will understand and believe whatever one must do to operate in a way acceptable to other members of that society through cultural learning. In fact, cultural information and proper behaviours are learnt through social interaction. As a result, culture at times is defined as appropriate engagement within a social group, which includes a way of life, a set of social practices, a set of beliefs, and a common history or collection of experiences (Yassine, 2006).

William (in Byram, 1992, p.120) defines culture throughout three dimensions: first, the area of the 'ideal' of certain universal values, in which culture is a state of human perfection or a process leading to it; second, the area of the 'ideal' of certain universal values, in which culture is a state of human perfection or a process leading to it. Then there's the 'documentary' sphere, where culture includes all intellectual and creative outputs and where thought and human experience are meticulously documented. Finally, there is a 'social' definition of culture, which defines it as a way of life that reflects specific meanings and values not only in the realms of art and knowledge but also in institutions and everyday behaviour. Considering language as a means of cultural analysis, on the other hand, allows for the exploration of its close link with cultural meanings, in addition to other forms of communication such as music, painting, and so on.

Others might link culture to norms like social interaction patterns, beliefs, ideas, and attitudes. So, when individuals think about culture, they generally think of things like food, dress, music, art, or literature, according to Frank (2013). There are many different definitions of culture, and teachers must define culture before students may participate in participatory 
cultural debates. Students can use the Standards for Foreign Language Learning (NSFLEP 1999) to integrate "philosophical ideas, behavioural practices, and products-both tangible and intangible- of a civilization" (47). The 3P model of culture has emerged because of this:

- Perspectives (what members of a culture think, feel, and value)

- Practices (how members communicate and interact with one another)

- Products (technology, music, art, food, literature, etc.; the things members of a group create, share, and transmit to the next generation) While objects are easy to detect because we can see, touch, taste, or hear them, opinions and behaviours are more difficult to define since they are ingrained in society.

In conclusion, culture is a combination of perspectives, practices, and products. Cultural assimilation can go through the three stages of food as a product of the culture that is practised through communication and social interaction. An example of cultural assimilation through food and social interaction is Thanksgiving, where there is food and social interaction.

\section{Past Studies}

How Millennials Accept New Cultures

In recent studies, the relationship between millennials and their acceptance of new cultures is mainly studied using quantitative methods like surveys. In this case, HansonRasmussen \& Lauver (2018) investigated students of diverse cultures, in the college of business in the United States, India, and China. consider obligation in caring for the environment and how these beliefs embody their cultural and millennial values. The finding uncovered that the majority consigned the responsibilities to 'all', and showed concern for future generations despite being optimistic. Oksa et al. (2021) examined the connection between social media use at work and welfare at work for millennials and members of previous generations in Finland by interviewing 52 respondents of a focus group, surveying 563 respondents in an expert organization, and 1817 respondents of national representatives. The survey revealed that millennials were not active in social media for work, however, they faced technostress and burnout compared to former generations.

Another trend that can be seen in recent studies regarding the millennial acceptance of new culture is the focus on technology usage in consumerism or employment. One example of a study is by Maimunah \& Hoo (2014), who developed a conceptual framework on the impact of cultural values on the career goals of the millennial generation in Malaysian employees. The conceptual framework build by Maimunah \& Hoo (2014) is based on a literature review made on several keywords in the university's library such as Proquest, SAGE, Emerald, EBSCO Host, Springer, Science Direct, Social Science Citation Index, and Blackwell Synergy. By adopting the six dimensions of Hofstede's cultural values, Maimunah \& Hoo (2014) created an integrated framework that summarizes the predictive potential of these values in clarifying career goals of the millennial generation and recommend practical interventions to the Human Resource Department in supervising younger workforce in the perception of career development. Meanwhile, Hur et al (2017) had analysed the effect of consumer technology and fashion innovativeness between millennial and mature consumers. Using the Technology Acceptance Model (TAM), Hur et al (2017) introduced an extra playfulness variable to confirm the association between variables linked to technological innovativeness and fashion innovativeness. Their findings show that there was a difference between millennial consumers than their mature counterparts where consumers who were familiar with technological innovativeness were inclined to find the fashion app simple to be 
used. However, those who are proficient with fashion innovativeness accepted the fashion service just because it was enjoyable to use rather than helpful or convenient.

In addition, the impact of a new culture on millennia's behaviour can also be seen as a frequent focus in current research. Cavaliere \& Ventura (2018) investigated the factors that impacted 1027 consumers' acceptance towards new technologies in the food, specifically Shelf-Life Extension which is deemed to be among the most sustainability-driving food innovations. Their results revealed that greater knowledge of food results in a higher level of acceptance but, on the contrary, a bigger interest in sustainability points to the rejection of technology. Similarly, Safeer et al (2021) investigated the effects of brand authenticity dimensions, which are quality commitment, heritage, sincerity, on-brand love, to predict millennia's behaviour through the context of Asia. Using Partial Least Squares Structural Equation Modelling (PLS-SEM), data on global brands are collected from 427 millennials from five Asian countries. The analysis uncovered that perceived brand authenticity dimensions prominently affected brand love, which influenced the outcomes of Asian millennials' behaviour (continuous purchase intention and price premium).

\section{Food as an Agent of Culture Immersion}

People's lifestyle, their environments, ingredients available, are usually influenced by their daily diet. Therefore, food is the best way to know the culture of a community. Fast food has become more popular compared to the local cuisine or traditional food served at home. Seo et al (2011) studied 354 middle school students' fast-food consumption and the factors that influenced it in Seoul. The result showed that the average monthly frequency of fast-food consumption is 4.05 . Fast food was considered a food that will be taken for special events most likely with friends.

Lusiana et al (2020) studied the impacts of globalization in the formation of identity and lifestyle in relation to Japanese food consumption, and the power of decision making in consuming Japanese food, based on the perspective of popular culture's influence in Purwokerto City, Central Java. The research subjects were the people of Purwokerto who consume Japanese food and the owners of the Japanese restaurant. The research on consumption experience was conducted with three groups of the society, namely 1) those who came to restaurants and ate Japanese food, 2) those who came to Japanese festivals, 3) Japanese food owners. This study found that the people in Purwokerto City not only love Japanese food but also have eleven Japanese culture lover communities. This showed that food can be the agent of cultural immersion.

Conceptual Framework

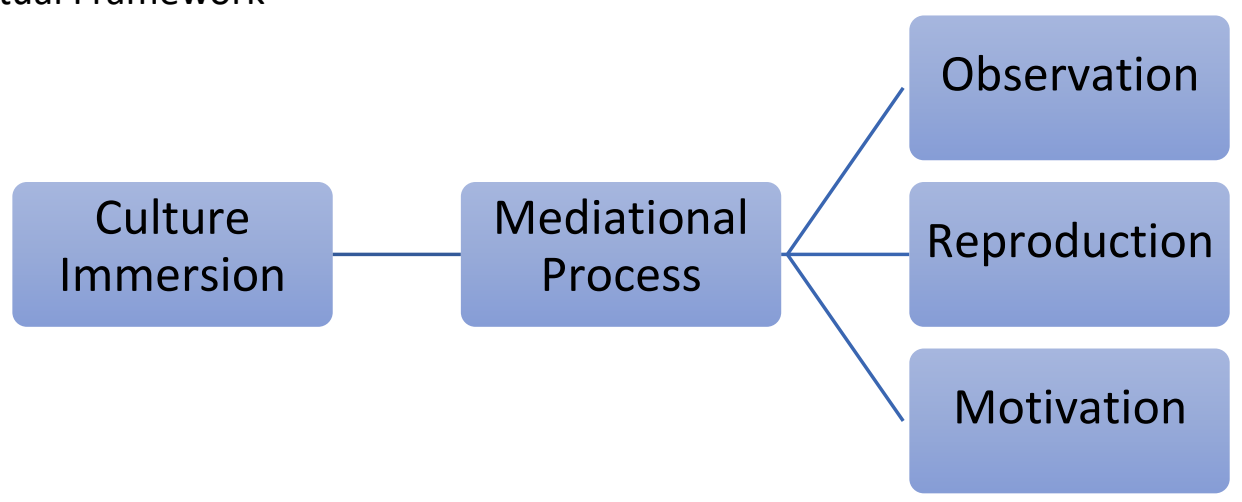

Figure 1: Conceptual Framework of the Study Source: Bandura (1977) 
Figure 1 above presents the conceptual framework of the study. One of the many ways of cultural immersion is through the mediational process that takes place in societies. According to Bandura (1977), mediational processes can be done through (a) observation, reproduction and (c) motivation. In the context of this study, the vehicle for a mediational process is done through the introduction of popular food.

\section{Methodology}

Research Design

This quantitative study is done to explore the mediational process from cultural immersion on the issue of a popular noodles-ramen. 530 participants were purposely chosen from young adults who consume ramen. The instrument (table 1) used is a survey with 18 items on what the respondents felt about the consumption of Ramen. SPSS analysis revealed a Cronbach alpha of .890 thus showing good reliability for the instrument. Data is analysed using SPSS version 26 to reveal percentages for the demographic profile and mean score for the items in the variables. Finds are presented in the form of pie charts and bar charts.

\section{Reliability Statistics}

\begin{tabular}{r|r}
$\begin{array}{c}\text { Cronbach's } \\
\text { Alpha }\end{array}$ & N of Items \\
\hline .890 & 18 \\
\hline
\end{tabular}

Table 1-Reliability Statistics 


\section{Findings}

Demographic Profile

Country

\section{$30 \%$}

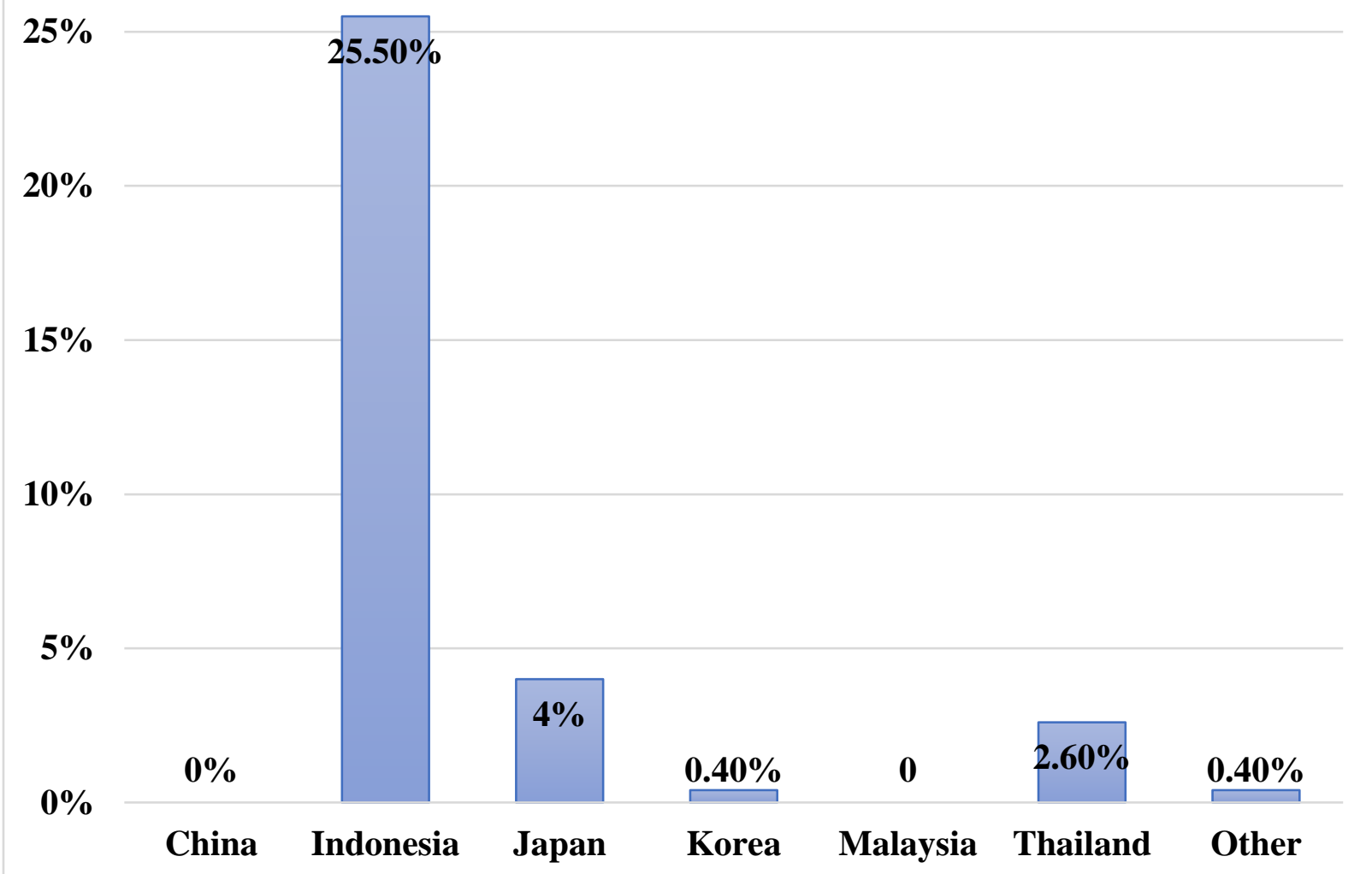

Figure 2- Percentage for Country

The respondents of this research come from several countries in Asia, but mostly (67\%) come from Malaysia. Then Indonesian comes next (25.5\%), Japanese $4 \%$, Thai $3 \%$, Korean $0.4 \%$, Chinese $0 \%$, and other countries $0.4 \%$

Gender

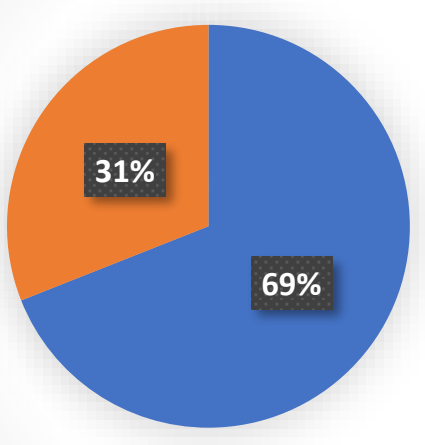

- Female

Male

Figure 3-Percentage for Gender 
Figure 2 shows respondents that come from both sexes. Females who responded to the observation are $69 \%$, far more than those of males (31\%).

Age

\section{$80.00 \%$}

$70.00 \%$

$60.00 \%$

$50.00 \%$

$40.00 \%$

$30.00 \%$

$20.00 \%$

$10.00 \%$

$0.00 \%$
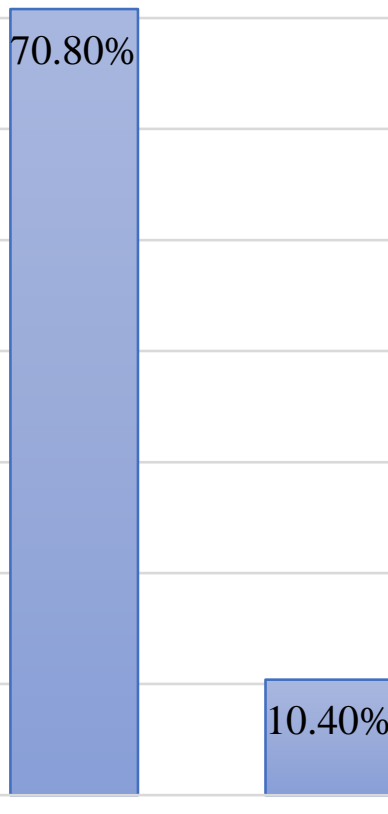

$0.40 \%$

$15-17$

$18-20$

$21-23$

24-26

27 above

Figure 4- Percentage for Age

Figure 4 shows respondents have different age backgrounds. but, mostly $(70,8 \%)$ were aged $21-23$ years, Than $18-20$ years comes next (18.1\%), $24-26$ years (10.4\%), 15-17 years and above 27 years with the same percentage $(0.4 \%)$

Studying Japanese in university

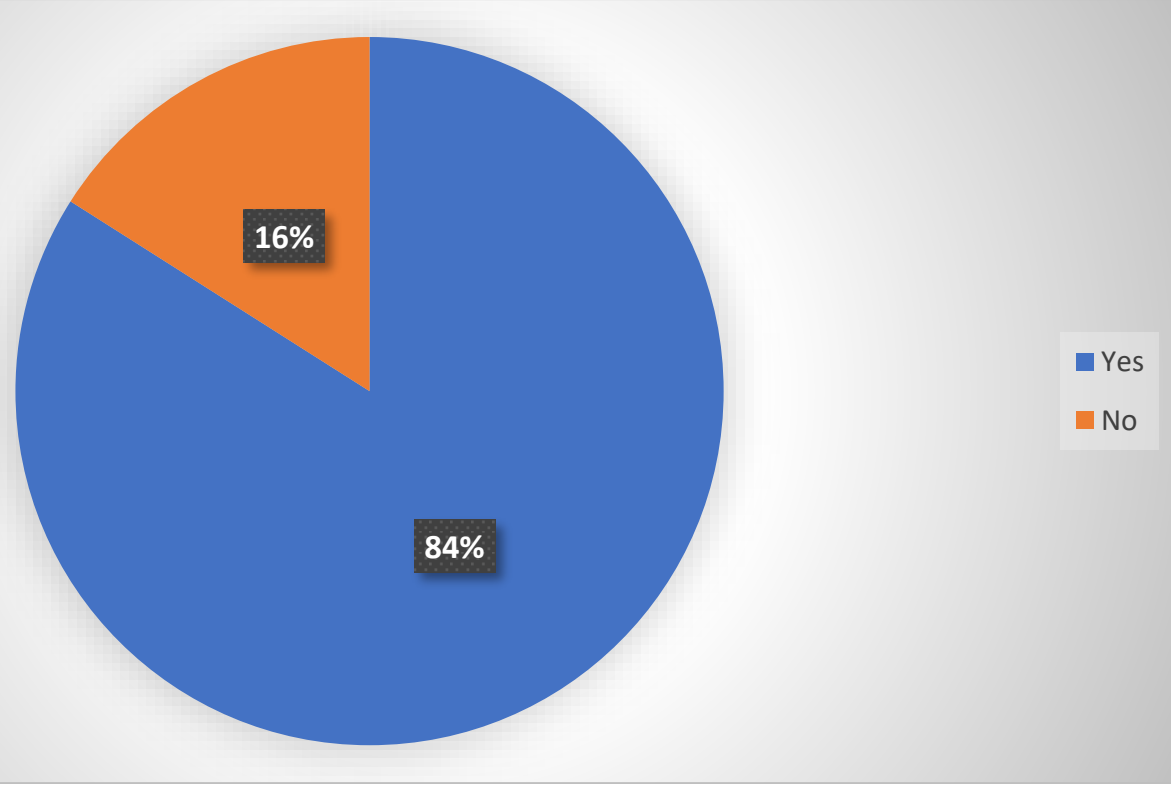

Figure 5- Percentage for Studying Japanese 
Figure 5 shows that most of the respondents are studying Japanese at University (84\%). While $16 \%$ do not study the Japanese language.

Findings for Observation (Perception of Ramen)

This section answers the first research question on "How is observation done through ramen?". The findings are revealed through the bar chart below on the perception of young adults on ramen.

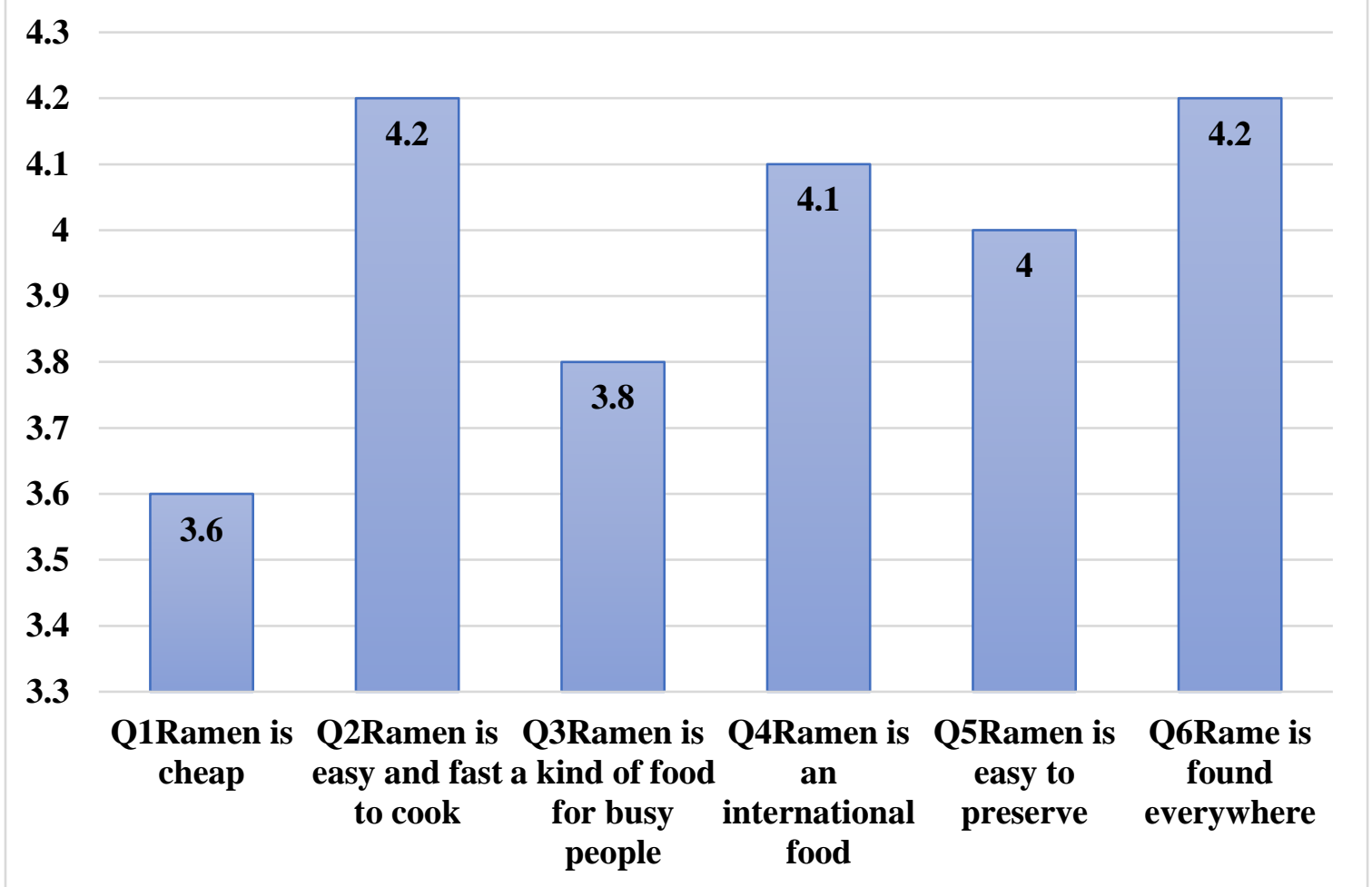

Figure 6- Mean Score for Observation

Figure 6 demonstrates the mean score on the perception of ramen among millennials. 6 questions were dedicated for this observation. The finding shows that the average mean for all 6 questions is around 3.6 to 4.2. Question number 2 and number 6 have the highest mean score where Ramen is perceived to be simple and quick to prepare, as well as, conveniently available everywhere. The second highest mean score is 4.1 , representing question 4 that reveals ramen to be a food that is eaten and known globally. With the difference of 0.1 from question number 4 , question number 5 scored 4.0 for its mean, revealing millennials' perception of ramen to be easily stored and kept as food. The second last question is number 3 with a 3.8 mean score where it is discovered that a lesser average number of Millenials found ramen to be convenient for busy people. The lowest mean score of 3.6 can be seen representing question number 1 where Millenials viewed ramen as cheap the least compared to other questions.

\section{Findings for Reproduction (Ramen and Social Interaction)}

This section answers the second research question on "How is a reproduction of habits done through ramen?". The findings reveal that consuming ramen helps younger adults to interact socially, especially with those with the same preference. 


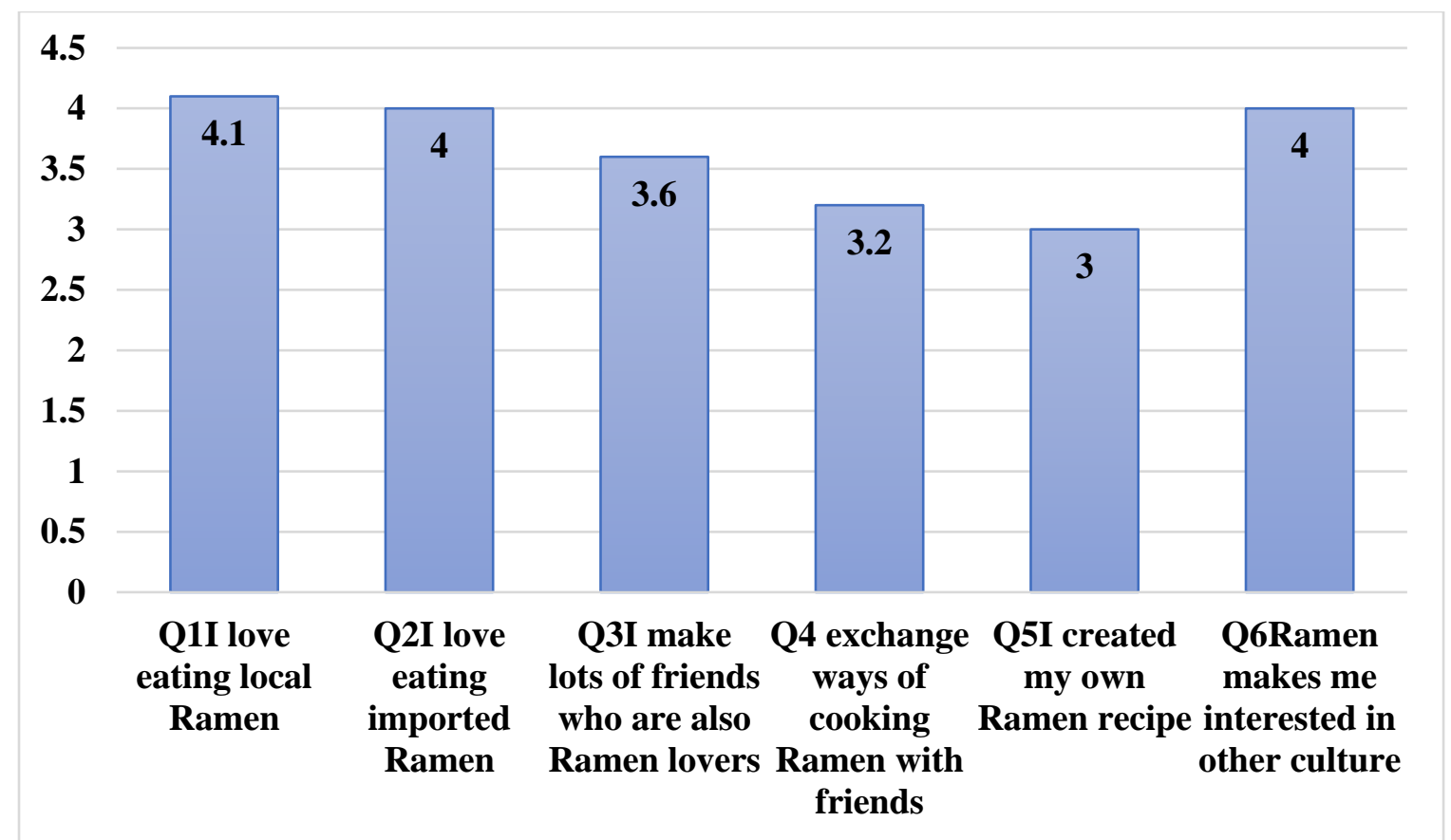

Figure 7- Mean Score for Reproduction

Figure 7 demonstrates the mean score for the reproduction of ramen and social interaction. There are 6 questions given in this observation. The average mean score is 3.65, and the range of the mean score is from 4.1 to 3 . The highest mean score is in question no 1 , which shows that the respondents love eating local ramen. This means that most of the respondents prefer local ramen compared to imported ramen. The second highest mean score came to 2 questions, i.e., question number 2 (the respondents love eating imported ramen) and question number 6 (ramen makes me interested in other cultures). This means that there is a connection between knowing food from different countries that make the respondents know more about the food origin culture. Question number 3 has a mean score of 3.6, where it reveals that through ramen young adults can make a lot of friends. Question number 3 has 3.2 as its mean score, and it reveals the respondents' willingness to exchange ways of cooking with friends. The lowest is question number 5 that has 3 as its mean score, which demonstrates that the respondents would like to make their own ramen recipe.

Ramen and Study Patterns (accommodation)

This section presents the answer to research question 3 which is "How is motivation enhanced through ramen?". The data reports how consumption of ramen has affected the young adults' study patterns. 


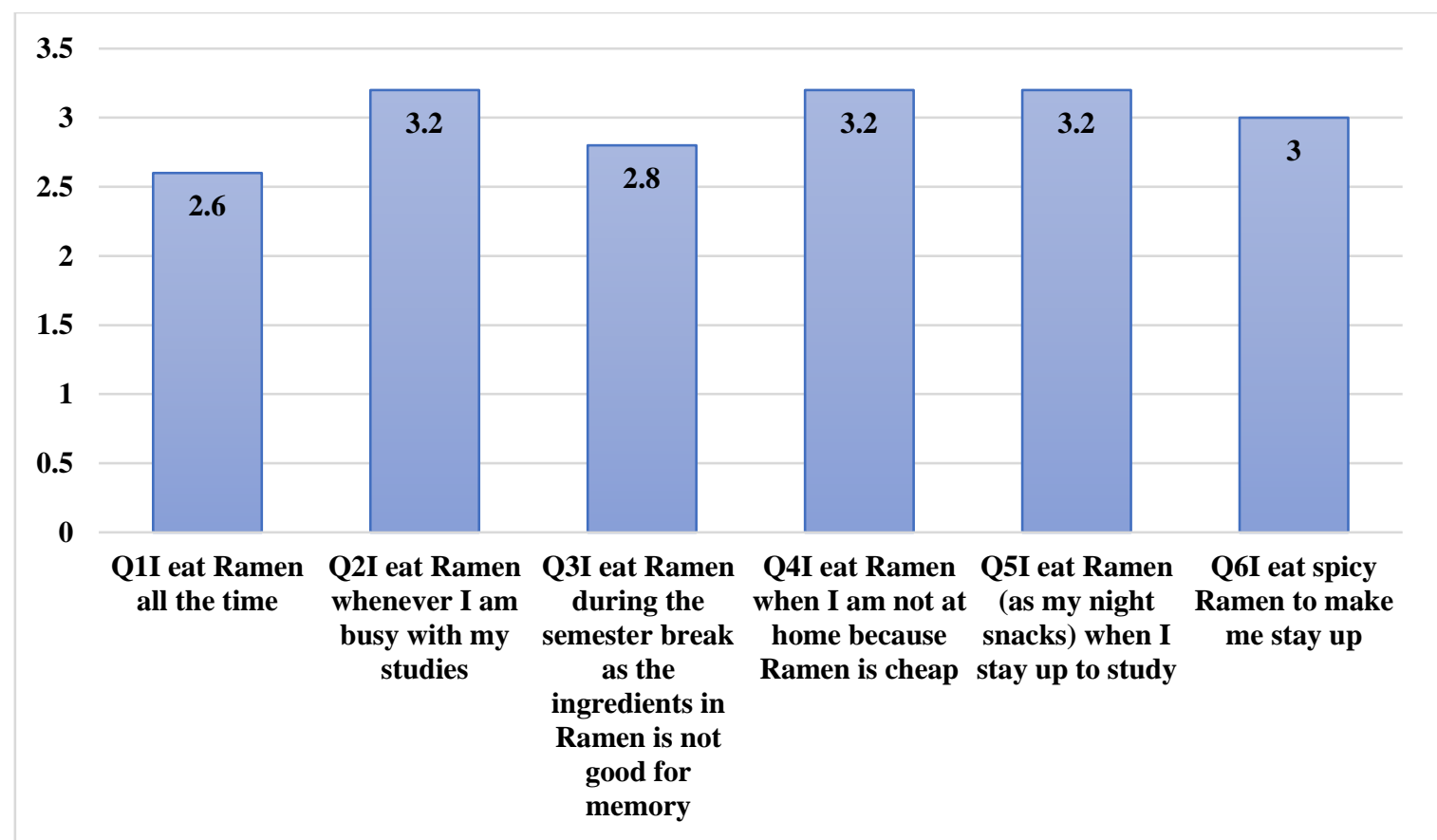

Figure 8- Mean Score for Study Patterns

Figure 8 indicates the pattern of respondents on what occasion they eat ramen. Respondents were given 6 questions during the observation. The average mean score is 3 . There are 3 questions (no 2, 4, and 5) that got the highest mean score, which is 3.2. The mean score demonstrates that the average respondents eat ramen either when they are busy with their studies, when they are not at home because ramen is cheap, or when they stay up to study as their night snacks. The second highest mean score is 3 , for question no 6 , which shows that respondents eat ramen to stay up at night. Next, the mean score of 2.8 for question number 3 indicates respondents eat ramen only during the semester break as they believe ramen has ingredients that are not good for their memory. The lowest mean score (2.6) is question number 1 , which shows that not many respondents eat ramen all the time.

\section{Conclusion}

Summary of Finding

The findings in this study have shown that young adults turn to Ramen for its convenience and its availability. Specifically, respondents reported that Ramen is Observed as a convenient food, and eating it enabled social interaction among "Ramen-eaters". In addition to that, respondents allowed the social habit of eating Ramen to influence their study patterns. This is also agreed by Errington et al (2013) and Choong et al (2012) who found that in this time-compressed society, people are constantly looking for short-cuts. Next findings also showed that respondents felt they were immersing themselves sin the culture that they liked. Maimunah \& Hoo (2014) reports that mirroring what the target culture does is a way of the young adults showing that they accepted other culture. Finally, findings also showed that many has turned to the consumption as a way of their life. The study by Seo et al (2011) also reports that eating is a way to socialize.

\section{Implications}

This Research implies that most of them come from Malaysia, Indonesia, Japan, Thailand, Korea, and other countries. With male gender. Dan has an age range of 21-23 years, 
18-20 years, 24-26 years, and is a student who is studying at the university. Millennials' perception of Ramen is that Ramen is easy and fast to cook, Ramen is found everywhere, Ramen is an international food. Another implication of the theory is regarding Ramen and Social Interaction) are they love eating local Ramen, the love eating imported Ramen, Ramen makes me interested in other cultures.

The respondents eat Ramen when they are busy with their studies, and they eat Ramen when they are not at home because Ramen is cheap, and they eat Ramen as their night snacks when they stay up to study. The second highest mean score is 3 , for question no 6 , which shows that respondents eat Ramen to make them stay up. Next, the mean score of 2.8 for question number 3 indicates respondents eat Ramen only during the semester break as they believe Ramen has ingredients that are not good for their memory. The lowest mean score (2.6) is question number 1 , which shows that not many respondents eat Ramen all the time. The research finding can provide implications in Japanese Culture lessons. Most of all respondents are studying Japanese at University. Ramen is one of the Japanese cultures. According to this study, we find that learning a foreign language is influences our behaviour in eat.

\section{Suggestions for Future Study}

Despite many respondents in this study, there is still space for improvement as well as the requirement to investigate different aspects in future research. It is recommended that future studies are done using a younger age range of respondents like Generation Alpha. On top of that, it would be interesting to focus on the comparison between two types of respondent groups either by age, gender, nationality, or other criteria. In addition, research on different aspects of food (like sushi or karee) and even clothing (such as kimono or yukata) would be a significant addition to this field. Finally, a study that utilizes a qualitative method (like interview) or combination of both quantitative and qualitative methods is also highly suggested to obtain more comprehensive results in the future.

\section{References}

Aznur, A., Zainah, A., \& Mimiko, N (2015). Japanese Food Product Purchase Intention: Comparing Students with and without Japanese Language Learning Experience. Procedia-Social and Behavioral Sciences, Vol 172, 27 January 2015, Pages 596-602. Retrieved from: http://doi.org/10.1016/j.sbspro.2015.01.408

Bandura, A. (1977). Social learning theory. Englewood Cliffs, NJ: Prentice Hall.

Basaran, G., \& Sunnetcioglu, S. (2021). Turkish anime viewer's approach to Japanese cuisine culture. Journal of Ethnic Foods (2021) 8:8. Retrieved from http://doi.org/10.1186/s42779-021-00085-5

Cavaliere, A., \& Ventura, V. (2018). Mismatch between food sustainability and consumer acceptance toward innovation technologies among Millennial students: The case of Shelf Life Extension. Journal of Cleaner Production, 175, 641-650. https://doi.org/10.1016/J.JCLEPRO.2017.12.087

Dzulkafli, N. H., Hamirudin, A. H., \& Sidek, S. (2020). Night Eating Syndrome and Its Association with Body Mass Index among Female University Students. International Journal of Allied Health Sciences Vol.4, No. 4(2020) 1626-1634. Retrieved from: https://journals.iium.edu.my/ijahs/index.php/IJAHS/article/view/462 
Edinyang, S. D. (2016). The Significance of Social Learning Theories in the Teaching of Social Studies Education. International Journal of Sociology and Anthrology Research, Vol.2, No. 1, pp 40-45, August 2016. Retrieved from: https://www.eajournals.org/journals/international-journal-sociology-anthropologyresearch-ijsar/vol-2-issue-1-august-2016/significance-social-learning-theoriesteaching-social-studies-education/

Errington, F., Gewertz, D., \& Fujikura, T. (2013). The Noodle Narratives. University of California Press 2013. Retrieved from: http://doi.org/10.1525/9780520956674Hidayat, D. \& Hidayat, Z. (2020). Anime as Japanese Intercultural Communication: A Study of the Weeaboo Community of Indonesian Generation $Z$ and Y. Romanian Journal of Communication and Public Relations Vol. 22, 3(51)/Dec 2020, 85-103. Retrieved from: http://doi.org/10.21018/rjcpr.2020.3.310

Frank Jerrold (2013). Raising cultural Awareness in the English Language Classroom. English Teaching Forum (2013) number 4.

Habib, F. Q., Dardak, R. A., Zakaria, S. (2011). Consumer's Preference and Consumption Towards Fast Food: Evidence from Malaysia. Business Management Quarterly Review, Vol.2, No.1, 2011. Pp 14-27. Retrieved from: https://ir.uitm.edu.my/id/eprint/880/1/AJ_FARZANA\%20QUOQUAB\%20HABIB\%20BM QR\%2011.pdf

Hanson-Rasmussen, N. J., \& Lauver, K. J. (2018). Environmental responsibility: millennial values and cultural dimensions. Journal of Global Responsibility, 9(1), 6-20. https://doi.org/10.1108/JGR-06-2017-0039

Hur, H. J., Lee, H. K., \& Choo, H. J. (2017). Understanding usage intention in innovative mobile app service: Comparison between millennial and mature consumers. Computers in Human Behavior, 73, 353-361. https://doi.org/10.1016/J.CHB.2017.03.051

Kostikova, L. P., Prishvina, V. V., Ilyushina, A. V., Fedotova, O. S., \& Belogurov, A. Y. (2018, March). Culture in teaching English as a foreign language. In 2nd International Conference on Culture, Education and Economic Development of Modern Society (ICCESE 2018) (pp. 13-17). Atlantis Press. https://www.atlantis-press.com/proceedings/iccese$18 / 25893858$

Kramsch, C. (2013). Culture in foreign language teaching. Iranian Journal of Language Teaching Research, 1(1), 57-78. https://eric.ed.gov/?id=EJ1127430

Li, Y. (2014, May). Discussion on Culture Introduction in Japanese Language Learning. In the International Conference on Education, Language, Art and Intercultural Communication. https://www.atlantis-press.com/proceedings/icelaic-14/12543

Lusiana, Y., Laksono, P. M., and Hariri, T. (2020). Self-Styling, Popular Culture, and the Construction of Global-Local Identity among Japanese Food Lovers in Purwokerto. IPop: International Journal of Indonesian Popular Culture and Communication, 1(1), 2140. http://doi.org/10.36782/i-pop.v1i1.33

Maimunah, I., \& Hoo, S. L. (2014). Cultural Values and Career Goals of the Millennial Generation: An Integrated Conceptual Framework. The Journal of International Management Studies, 9(1), 38-49.

Mazari, A., \& Derraz, N. (2015). Language and Culture. International Journal of Humanities and Cultural Studies ISSN 2356-5926, Vol 2, Issue 2 September 2015. Pp 350-359. Retrieved from: http://www.ijhcs.com/index.php/ijhcs/article/view/492

Oksa, R., Saari, T., Kaakinen, M., \& Oksanen, A. (2021). The motivations for and well-being implications of social media use at work among millennials and members of former 
generations. In International Journal of Environmental Research and Public Health (Vol. 18, Issue 2, pp. 1-22). https://doi.org/10.3390/ijerph18020803

Pourkalhor, O., \& Esfandiari, N. (2017). Culture in Language Learning: Background, Issues and Implications. International Journal of English Language \& Translation Studies. 5(1), 2332. http://eltsjournal.org/archive/value5\%20issue1/4-5-1-17.pdf

Rabbani, F. (2015). The Millennial Genaration and Popular Culture in EFL Classroom. Indonesian EFL Journal, Vol. 1, No. 1(2015) pp. 88-97.DOI:

http://doi.org/10.25134/ieflj.v1i1.618

Safeer A. A., He Y., Lin Y., Abrar M., \& Nawaz Z. (2021). Impact of perceived brand authenticity on consumer behavior: an evidence from generation $Y$ in Asian perspective. International Journal of Emerging Markets. https://www-scopuscom.ezaccess.library.uitm.edu.my/record/display.uri?eid=2-s2.085106224812\&origin=resultslist\&sort=plf$\mathrm{f} \& \mathrm{src}=\mathrm{s} \& \mathrm{sid}=247308873 f 752482 \mathrm{e} 12 \mathrm{a} 80036 \mathrm{a} 53 \mathrm{a} 769 \& \mathrm{sot}=\mathrm{b} \& \mathrm{sdt}=\mathrm{b} \& \mathrm{sl}=42 \& \mathrm{~s}=\mathrm{TITLE}-$ ABS-KEY\%28Millennials+AND+new+culture\%29\& relpos=5\&citeCnt=0\&searchTerm $=$

Sheahan, P. (2008). Generation Y in Asia. Retrieved from: http://worldwide.streamer.espeakers.com/assets/9/8099/30062.pdf

Sheahan, P. (2011). Generation Y in Asia: In the face of a talent crisis, companies are facing up to the challenges of the world's most powerful emerging consumers, clients, and employees. Retrieved from:

http://worldwide.streamer.espeakers.com/assets/9/8099/30062.pdf

Sun, L. (2013). Culture Teaching in Foreign Language Teaching. Theory \& Practice in Language Studies, 3(2). doi:10.4304/tpls.3.2.371-375.

https://www.academypublication.com/issues/past/tpls/vol03/02/21.pdf

Taylor, P., Keeter, S. (2010) Millennials: Confident, Connected, Open to Change. Pew Research Center. Retrieved from: https://eric.ed.gov/?id=ED575464 